\title{
Energy Systems Integration: Defining and Describing the Value Proposition
}

O'Malley, Mark; Kroposki, Benjamin; Hannegan, Bryan; Madsen, Henrik; Andersson, Mattias; D’haeseleer, William ; McGranaghan, Mark F. ; Dent, Chris; Strbac, Goran; Baskaran, Suresh Total number of authors: 11

Link to article, DOI:

$10.2172 / 1257674$

Publication date:

2016

Document Version

Publisher's PDF, also known as Version of record

Link back to DTU Orbit

Citation (APA):

O'Malley, M., Kroposki, B., Hannegan, B., Madsen, H., Andersson, M., D’haeseleer, W., McGranaghan, M. F., Dent, C., Strbac, G., Baskaran, S., \& Rinker, M. (2016). Energy Systems Integration: Defining and Describing the Value Proposition. International Institute for Energy Systems Integration. https://doi.org/10.2172/1257674

\section{General rights}

Copyright and moral rights for the publications made accessible in the public portal are retained by the authors and/or other copyright owners and it is a condition of accessing publications that users recognise and abide by the legal requirements associated with these rights.

- Users may download and print one copy of any publication from the public portal for the purpose of private study or research.

- You may not further distribute the material or use it for any profit-making activity or commercial gain

- You may freely distribute the URL identifying the publication in the public portal 


\section{Energy Systems Integration: Defining and Describing the Value Proposition}

Mark O'Malley

University College Dublin

Benjamin Kroposki and Bryan Hannegan

National Renewable Energy Laboratory

Henrik Madsen and Mattias Andersson

Technical University of Denmark

William D'haeseleer

KU Leuven

Mark F. McGranaghan

Electric Power Research Institute

Chris Dent

Durham University

Goran Strbac

Imperial College London

Suresh Baskaran and Michael Rinker

Pacific Northwest National Laboratory

Technical Report

NREL/TP-5D00-66616

June 2016

DOI link: http://dx.doi.org/10.2172/1257674

Contract No. DE-AC36-08GO28308 


\title{
Energy Systems Integration: Defining and Describing the Value Proposition
}

\author{
Mark O’Malley \\ University College Dublin
}

Benjamin Kroposki and Bryan Hannegan

National Renewable Energy Laboratory

Henrik Madsen and Mattias Andersson

Technical University of Denmark

William D'haeseleer

KU Leuven

Mark F. McGranaghan

Electric Power Research Institute

Chris Dent

Durham University

Goran Strbac

Imperial College London

Suresh Baskaran and Michael Rinker

Pacific Northwest National Laboratory

The International Institute for Energy

Systems Integration

15013 Denver West Parkway

Golden, CO 80401

303-275-3000 • www.iiesi.org

\section{Technical Report}

NREL/TP-5D00-66616

June 2016

Contract No. DE-AC36-08G028308 


\section{NOTICE}

This report was prepared as an account of work sponsored by an agency of the United States government. Neither the United States government nor any agency thereof, nor any of their employees, makes any warranty, express or implied, or assumes any legal liability or responsibility for the accuracy, completeness, or usefulness of any information, apparatus, product, or process disclosed, or represents that its use would not infringe privately owned rights. Reference herein to any specific commercial product, process, or service by trade name, trademark, manufacturer, or otherwise does not necessarily constitute or imply its endorsement, recommendation, or favoring by the United States government or any agency thereof. The views and opinions of authors expressed herein do not necessarily state or reflect those of the United States government or any agency thereof.

Available electronically at SciTech Connect: $\underline{\text { htpp:/www.osti.gov/scitech }}$

Available for a processing fee to U.S. Department of Energy and its contractors, in paper, from:

U.S. Department of Energy

Office of Scientific and Technical Information

P.O. Box 62

Oak Ridge, TN 37831-0062

OSTI: http://www.osti.gov

Phone: 865.576 .8401

Fax: 865.576.5728

Email: reports@osti.gov

Available for sale to the public, in paper, from:

U.S. Department of Commerce

National Technical Information Service

5301 Shawnee Road

Alexandria, VA 22312

NTIS: http://www.ntis.gov

Phone: 800.553 .6847 or 703.605 .6000

Fax: 703.605.6900

Email: orders@ntis.gov 


\section{Introduction}

\section{What is Energy Systems Integration (ESI)?}

Energy Systems Integration (ESI) is the process of coordinating the operation and planning of energy systems across multiple pathways and/or geographical scales to deliver reliable, costeffective energy services with minimal impact on the environment.

\section{Global energy trends}

Energy systems have evolved from individual systems with little or no dependencies into a complex set of integrated systems at scales that include customers, cities, and regions. This evolution has been driven by political, economic, and environmental objectives. As we try to meet the globally recognized imperative to reduce carbon emissions through the deployment of large renewable energy capacities while also maintaining reliability and competiveness, flexible energy systems are required. This flexibility can be attained through integrating various systems: by physically linking energy vectors, namely electricity, thermal, and fuels; by coordinating these vectors across other infrastructures, namely water, data, and transport; by institutionally coordinating energy markets; and, spatially, by increasing market footprint with granularity all the way down to the customer level (Figure 1).

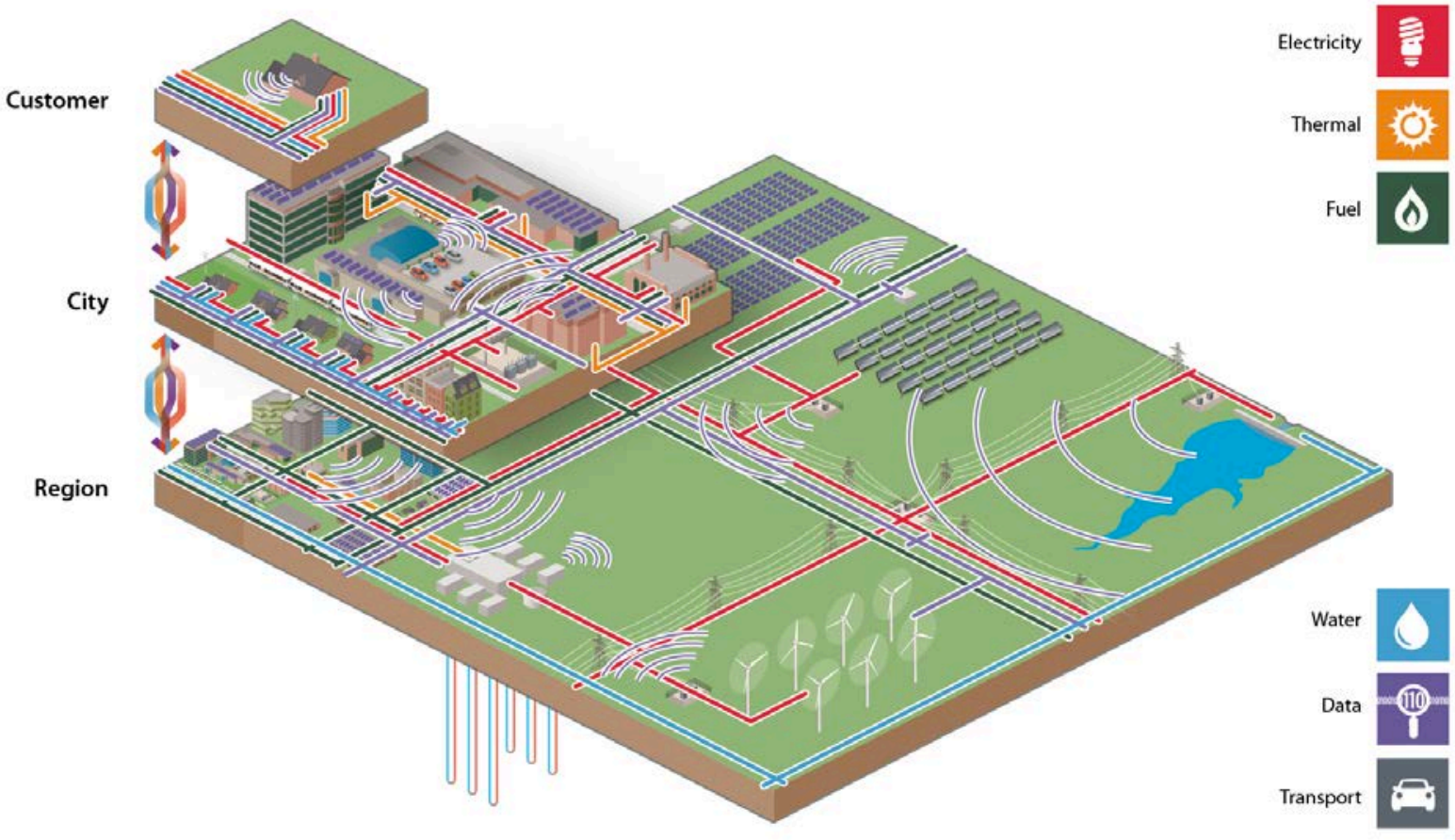

Figure 1: Energy Systems Integration 
The International Energy Agency estimates that approximately $€ 7.4$ trillion will be invested over the next 25 years in executing the shift to renewable energy sources. This represents only $15 \%$ of the total investment in global energy supply and is not enough to meet climate change targets. The recent Conference of Parties 21 (COP 21) agreement has given further momentum to this renewable energy trend-which necessitates the development of flexible, integrated energy systems.

ESI is one of several global social and engineering trends that will shape the solutions to the key challenges of the next decades: resource stress, climate change, megacities, urbanization, cybersecurity, and infrastructure resilience. ESI is an umbrella concept that encompasses activities tackled in the context of smart grids (grid modernization) and smart cities. However, these two approaches are more limited, with one focused on a single energy vector (electricity) and the other limited in geographical scale to a city-so they may miss important opportunities that can arise by considering all energy vectors and all scales.

\section{Policy relevance}

The importance of ESI is being recognized globally. Most significantly, ESI is a central theme running through the European Commission's Strategic Energy Technology (SET) Plan Integrated Roadmap. It is also a central theme of the Clean Energy Ministerial and a major research theme with the U.S. Department of Energy national laboratory complex. There is also a new European Energy Research Alliance Joint Programme in ESI.

It is imperative that stakeholders gain a better understanding of what ESI is and how we can use it to achieve a low-carbon energy system with affordable, efficient, and secure supplies of energy. This requires a concerted effort to:

- Communicate the importance of ESI to all stakeholders, which in turn should help focus attention and resources to related challenges and opportunities;

- Encourage and support dedicated education programs, which will help produce the human resources required to deliver on the potential of ESI; and

- Highlight the importance of breakthroughs in ESI and promote knowledge creation and transfer.

This paper defines what ESI is and the value of this approach.

\section{Defining ESI}

We define ESI in the following way:

Energy Systems Integration (ESI) is the process of coordinating the operation and planning of energy systems across multiple pathways and/or geographical scales to deliver reliable, cost-effective energy services with minimal impact on the environment. 
ESI includes interactions among energy vectors (electricity, thermal, and fuels) and interactions with other large-scale infrastructures including water, transport, and data and communications networks - which are an enabling technology for ESI. ESI is most valuable at the physical, institutional, and spatial interfaces, where there are new challenges and opportunities for research, demonstration, and deployment to reap its commercial and societal benefits. ESI is a multidisciplinary area ranging from science, engineering, and technology to policy, economics, regulation, and human behavior. It is this focus simultaneously on breadth and depth that makes ESI such a challenging and exciting area.

\section{Every system is different}

Each energy system will approach ESI from a different starting point (e.g., an urban area in the developed world will have a different approach compared to a rural area in the developing world). It is crucial to define the geographical scope as well as the components, the boundaries, and the influence of the surroundings. For example, renewable integration is the driving force of ESI in many regions, but not all. In some regions, the main drivers are increased combined heat and power (CHP), increased efficiency, a shift from coal generation to natural gas, or simply electrification. Different incentives, decision-making processes, and access to capital due to location or scale will result in very different energy systems and approaches to ESI (e.g., a government can invest in highvoltage transmission, while individuals will not). As each energy system develops, it will be necessary to constantly re-evaluate the system in order to assess how it is best coordinated.

\section{Every actor is different}

Developing coordinated systems through ESI analysis requires a proper understanding of the different actors involved, along with their motivations, their incentives, and the information they have access to. From a whole-system perspective, the actors in each energy domain tend to act on the information they have in ways that maximize benefits for their domain, but not for the entire energy system. For example, each user consumes based on their own requirements, each market values certain financial outcomes, and each government serves its own social or political motivations - but there may be no coordination across these domains to determine the best option for all actors involved. Poor outcomes can potentially arise from this lack of information and/or coordination, and may not be monetary in nature; a poorly executed energy transition could result in energy systems that lack technical integrity, social equity, and/or political acceptability.

\section{What is the value of ESI}

The value of ESI can be summarized as follows:

The value of ESI is in coordinating how energy systems produce and deliver energy in all forms to reach reliable, economic, and or environmental goals at appropriate scales. Analysis and design of integrated energy systems can inform policymakers and industry on the best strategies to accomplish these goals. 
Because ESI is a broad topic that includes all types of energy sources and end-use applications, it is helpful to categorize examples of ESI into a few areas. Here we provide several examples of ESI that have been organized into three "opportunity areas": streamline, synergize, and empower (Figure 2). These categories help differentiate how various ESI approaches can offer solutions to issues that have risen to the top of international energy agendas.

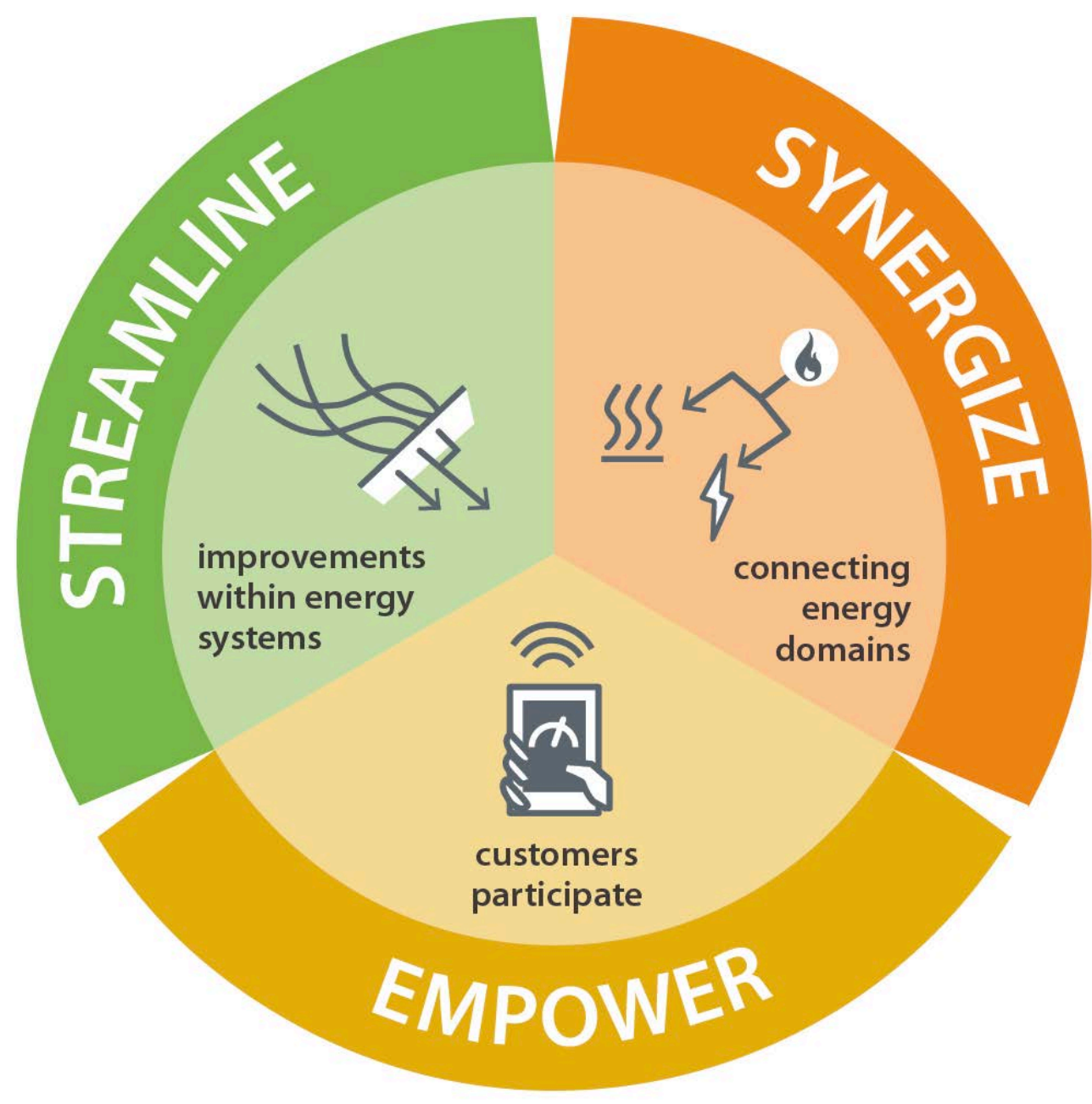

Figure 2: Opportunity areas for ESI

Streamline refers to improvements made within the existing energy system by restructuring, reorganizing, and modernizing current energy systems through institutional levers (i.e., policies, regulations, and markets) or investment in infrastructure. Increasing the flexibility of energy end use has potential system-wide benefits and could create new markets for products and services. However, capturing these benefits will require proper regulatory and market structures, new operational and planning paradigms, physical energy network characteristics, an integrated communications system, and suitably flexible end-use products. Many of these are currently lacking in the existing energy system and require a system-wide understanding to deliver pragmatic and sustainable solutions. Developing more integrated energy system-wide policies will enable better management of uncertainties. More integrated energy networks and proper functioning real-time 
locational markets will reward capacity and flexibility. In addition, the removal of institutional barriers between distribution and transmission systems will allow better integration of distributed resources and facilitate regional integration. By providing standardized requirements, updated interconnection and interoperability standards and grid codes will streamline the energy sector.

Investment in the appropriate infrastructure within the integrated energy system will improve flexibility. Expansion of the electrical transmission grid will enable flexibility by aggregation across scales. Pipeline infrastructure is required to increase the penetration of bio and/or synthetic fuels. Investment in data infrastructure will enable consumers to more fully participate in the energy system and will improve energy network operations through forecasting and analytics.

Synergize describes ESI solutions that connect energy systems between energy domains and across spatial scales to take advantage of benefits in efficiency and performance. To date, the coupling of heat and electricity sectors has focused on the supply side (e.g., CHP) for fuel-saving purposes. However, at the system level, its inherent inflexibility can lead to sub-optimal overall system performance. A good example of this is wind curtailment in China, which is in part due to the inability of physically inflexible CHP plants to reduce electricity production while providing heat. ESI solutions that integrate heat storage into the CHP plant are being developed and indicate a shift from the supply side to the demand side (e.g., electrical heating of water, thermal storage in buffers and heat pumps). It is possible to capitalize on "virtual storage" where the flexibility in one part of the system (e.g., heat, transport, water, etc.) can be integrated with, for example, the electricity system, and used in a similar manner to electricity storage. This virtual storage can be significantly cheaper than dedicated storage, as it does not require large capital investment-but it does require a more integrated energy system. Demand management (e.g., controlling heating and cooling loads) technologies currently being deployed and developed are in part leveraging this virtual storage. However, ESI proposes that it is at a grand scale where fuel, thermal, water, and transport systems will be systematically planned, designed, and operated as flexible "virtual storage" resources for the electricity grid (and vice versa). There is also the potential to use the natural gas fuel grid to create energy storage through the "power-to-gas" concept.

Empower refers to ESI actions that include the consumer, whether through their investment decisions, their active participation, or their decisions to shift energy modes. Investments in energy efficiency are increasingly recognized as a cost-effective way to reduce energy demand and can lead to system-wide benefits that include upstream capital and operational savings. From an overall energy system point of view, energy efficiency at the level of an individual building may be in conflict with the flexibility that the demand side can provide to the grid. Energy efficiency improvements or targets also contribute to broader social and policy goals, notably macro-economic efficiency, industrial productivity, public budget balance, security of supply, and health benefits. This buildinglevel investment needs to be made by the consumer. The formerly totally separated sectors of transport and electricity may become more integrated through plug-in electric (hybrid) vehicles and car batteries, but the consumer needs to accept this mode of transport. The potential in some regions for thermal grids has been raised, but questions remain as to how large they should be, how best to integrate them into the electricity grid, and, importantly, how consumer requirements will be ensured and whether consumers will accept them. Consumers can also make choices that provide them with the necessary services while using less energy by mode shifting. For example, consumers can choose to take public transport instead of personal transport. 
The considerations that govern ESI are numerous and complex, and the outcomes and their value can be difficult to define. One of the first steps to determine this value is to define a set of robust metrics spanning the engineering and social sciences (e.g., financial impacts, emissions costs, resiliency, public health considerations, social utility, etc.) to measure and highlight the various benefits. Any set of definitions or metrics will have to be flexible enough to accommodate a wide range of circumstances. Metrics also need to be simple enough to allow for an overall holistic understanding of how the different aspects interact.

\section{Conclusions}

ESI is an important concept to make the energy system more flexible, enable the efficient integration of renewable energy and to reduce carbon emissions. ESI solutions can range from the very simple to the very complex, are system specific, and impact different actors in distinct ways. They can require expertise from a single discipline or from a multitude of disciplines. It is important to understand the ESI value proposition and to communicate it in order to educate energy professionals and foster knowledge creation and transfer. 


\section{Reading list}

Auverlot, D., Beeker, E., Hossie, G., Oriol, L., Rigard-Cerison, A., Bettzüge, M. O., Helm, D. and Roques, F. (2014) 'The crisis of the European electricity system diagnosis and possible ways forward', Commissariat general à la Stratégie, Paris.

http://www.strategie.gouv.fr/sites/strategie.gouv.fr/files/archives/CGSP Report European Electrici ty System 030220141.pdf

Bird, L., McLaren, J., Heeter, J., Linvill, C., Shenot, J., Sedano, R., and Migden-Ostrander, J. (2013) 'Regulatory Considerations Associated with the Expanded Adoption of Distributed Solar', National Renewable Energy Laboratory (NREL), Golden.

http://www.nrel.gov/docs/fy14osti/60613.pdf

Booz \& Company, Newbery, D., Strbac, G., Pudjianto, D., and Noel, P. (2013) 'Benefits of an integrated European energy market', European Commission Directorate-General - Energy, Brussels. http://ec.europa.eu/energy/infrastructure/studies/doc/20130902 energy integration benefits.pdf

Chaudry, M., Jenkins, N., Qadrdan, M. and Wu, J. (2014) 'Combined gas and electricity network expansion planning', Applied Energy, 113, pp. 1171-1187.

Chen, X., Kang, C., O'Malley, M.J., Xia, Q., Bai, J., Liu, C., Sun, R., Wang, W. and Hui, L. (2014) 'Increasing the Flexibility of Combined Heat and Power for Wind Power Integration in China: Modelling and Implications', IEEE Transactions on Power Systems, 99, pp. 1-10.

Clean Energy Ministerial

http://www.cleanenergyministerial.org/Our-Work/Energy-Systems-and-Integration

Cochran, J., Bird, L., Heeter, J. and Arent, D. A. (2012) 'Integrating Variable Renewable Energy in Electric Power Markets: Best Practices from International Experience', National Renewable Energy Laboratory (NREL), Golden.

http://www.nrel.gov/docs/fy12osti/53732.pdf

DOE (2014) 'The water-energy nexus: challenges and opportunities,' Washington, DC. http://energy.gov/sites/prod/files/2014/06/f16/Water\%20Energy\%20Nexus\%20Report\%20June\%20 2014.pdf

EC (2012) 'Study on synergies between electricity and gas balancing markets', Brussels. http://ec.europa.eu/energy/gas electricity/studies/doc/20121220 ebegs final report.pdf

EERA (2014) 'Upcoming EERA JP Energy Systems Integration'. http://www.eera-set.eu/eera-joint-programmes-jps/15-eera-joint-programmes/upcoming-eerajoint-programmes/upcoming-eera-jp-energy-systems-integration/

Energy Systems Integration Facility

http://www.nrel.gov/esif/ 
EPRI (2014) 'The Integrated Grid: Realizing the Full Value of Central and Distributed Energy Resources'.

http://www.epri.com/abstracts/Pages/ProductAbstract.aspx?Productld=000000003002002733

EU Strategic Energy Technology (SET) Plan; Towards an Integrated Roadmap https://setis.ec.europa.eu/system/files/Towards\%20an\%20Integrated\%20Roadmap 0.pdf

Galus, M.A., Waraich, R.A., Noembrini, F., Steurs, K., Georges, G., Boulouchos, K., Axhausen, K.W. and Andersson, G. (2012) 'Integrating power systems, transport systems and vehicle technology for electric mobility impact assessment and efficient control', IEEE Transactions on Smart Grid, 3 (2), pp. 934-949.

GE (2013) 'Age of gas and power of networks'.

http://www.ge.com/sites/default/files/GE Age of Gas Whitepaper 20131014v2.pdf

Goldman, C., Reid, M., Levy, R. and Silverstein, A. (2010) 'Coordination of energy efficiency and demand response', Ernest Orlando Lawrence Berkeley National Laboratory, Berkeley.

Holttinen, H, Kiviluoma, J., Robitaille, A., Cutululis, N.A., Orths, A., van Hulle, F., Pineda, I, Lange, B., O'Malley, M., Dillon, J., Carlini, E.M., Vergine, C., Kondoh, J., Gibescu, M., Tande, J.O., Estanqueiro, A., Gomez, E., Söder, L., Smith, J.C., Milligan, M. and Lew, D. (2013) 'Design and operation of power systems with large amounts of wind power', Final summary report, IEA WIND Task 25, Phase 2 20092011.

http://www.vtt.fi/inf/pdf/technology/2012/T75.pdf

IEA (2015) 'World Energy Outlook', IEA/OECD, Paris.

Kiviluoma, J. and Meibom, P. (2010) 'Influence of wind power, plug-in electric vehicles, and heat storages on power system investments', Energy, 35 (3), pp. 1244-1255.

KPMG (2014) 'Future State 2030: The global megatrends shaping governments', http://www.kpmg.com/Global/en/IssuesAndInsights/ArticlesPublications/future-stategovernment/Documents/future-state-2030-v3.pdf

Krause, T., Andersson, G., Fröhlich, K. and Vaccaro, A. (2011) 'Multiple-energy carriers: modeling of production, delivery, and consumption', IEEE Proceedings, 99 (1), pp. 15-27.

Krishnan, V., Das, T., Ibanez, E., Lopez, C.A. and McCalley, J.D. (2013) 'Modelling operational effects of wind generation within national long-term infrastructure planning software', IEEE Transactions on Power Systems, 28 (2), pp. 1308-1317.

Kroposki, B., Garrett, B., Macmillan, S., Rice, B., Komomua, C., O’Malley, M.J. and Zimmerle, D. (2012) 'Energy systems integration, A convergence of ideas', Technical Paper NREL/TP-6A00-55649, National Renewable Energy Laboratory, Boulder. http://www.nrel.gov/docs/fy12osti/55649.pdf 
Kroposki, B. (2015). 'Energy Storage in the Future Grid', IEEE Electrification Magazine, 3 (3), pp. 6462.

Mathiesen, B.V., Lund, H., and Nørgaard, P. (2008) 'Integrated transport and renewable energy systems', Utilities Policy, 16 (2), pp. 107-116.

Miller, M., Bird, L., Cochran, J., Milligan, M., Bazilian, M., Neuhoff, K., Denny, E., Dillon, J., Bialek, J. and O'Malley, M.J. (2013) RES-E-NEXT, 'Next Generation of RES-E Policy Instruments', IEA RETD. http://iea-retd.org/wp-content/uploads/2013/07/RES-E-NEXT IEA-RETD 2013.pdf

NERC (2010) Special report: 'Flexibility requirements and potential metrics for variable generation: implications for system planning studies', Atlanta.

http://www.nerc.com/docs/pc/ivgtf/IVGTF Task 14 Final.pdf

O'Malley, M.J. and Kroposki B. (2013) 'Energy comes together the integration of all systems', Editorial, Special issue in Energy Systems Integration, IEEE Power \& Energy Magazine, 11, pp. 18-23.

Olsson, G. (2012) 'Water and energy threats and opportunities, the International Water Association', ISBN: 9781780400266.

Ruth, M. and Kroposki, B. (2014) 'Energy Systems Integration: An Evolving Energy Paradigm' The Electricity Journal, 27(6), pp. 36-47.

Unsihuay-Vila, C., Marangon-Lima, J.W., Zambroni de Souza, A.C., Perrez-Arriaga, I. J. and Balestrassi, P. P. (2010) 'A model to long-term, multiarea, multistage, and integrated expansion planning of electricity and natural gas systems', IEEE Transactions on Power Systems, 25 (2), pp. 1154-1168.

VDE (2012) 'Renewable energy needs flexible power plants: scenarios to 2020', Association for Electrical, Electronic \& Information Technologies, Offenbach am Main. 